Cite this: DOI: $10.1039 / x x x x x x x x x x$

Received Date

Accepted Date

DOI: 10.1039/xxxxxxxxxx

www.rsc.org/journalname

\section{Exploring discharged dry cell as an electrocatalyst for oxygen evolution reaction ${ }^{\dagger}$}

\author{
Pitchiah Esakki Karthik, ${ }^{* a}$ Sanjit Mondal, ${ }^{a}$, Lipipuspa Sahoo, ${ }^{a}$ and Ujjal K. Gautam ${ }^{a}$
}

\begin{abstract}
High oxophilic d-block compounds of dry cell based manganese materials such as $\mathrm{MnO}_{2}, \mathrm{Mn}_{3} \mathrm{O}_{4}$, and $\mathrm{Zn}_{x} \mathrm{Mn}_{3} \mathrm{O}_{4-x}$ have excellent electrocatalytic property in oxygen evolution reaction (OER). To seek a way for disposing these dry cell materials, which are unlike rechargeable batteries, these discharged cells result in environmental hazards. Here we optimized these manganese oxides for an energy related applications, particularly for OER. With this aim, we have examined electrocatalytic behavior of both used and fresh dry cells in OER. We have observed that the used dry cell material exhibited $10 \mathrm{~mA} . \mathrm{cm}^{-2}$ at an overpotential of $525 \mathrm{mV}$ but fresh dry cell needed $100 \mathrm{mV}$ higher overpotential to achieve same current density. The nature of these fresh and used materials have been analyzed using XRD, SEM, TGA, Raman spectra, FT-IR and contact angle experiments. The higher activity of used dry cell could be ascribed to the generation of highly active $\mathrm{Mn}_{3} \mathrm{O}_{4}$ from $\mathrm{MnO}_{2}$ and graphene oxide while discharging conditions.
\end{abstract}

\section{Introduction}

Drycell is an old technology to generate electricity from chemical energy for commercial applications, which utilizes chemical potential difference between manganese oxide $\mathrm{e}^{1}$ and zinc metal. 223]. Due to high abundance of manganese oxides on our earth crust, the dry cell productions and usages are huge. After Iron, aluminium and copper, manganese is consumed more by humans and it is placed at fourth position. While considering the consumption of Manganese, it is mainly used in steel industry, ${ }^{4}$ dry cell productions, ${ }^{2}$ as an oxidation catalyst and pigments ${ }^{5}$ for chemical companies.6 ${ }^{6}$ As a result of these continuous supply of Mn to versatile applications, there is a decrease in the percentage of $\mathrm{Mn}$ in soil. ${ }^{7}$ Among all applications, because of irreversible oxide's reduction nature of manganese, it's application is restricted and this happens especially in dry cells, therefore after used they are considered to be waste materials. $\frac{\sqrt{8}}{}$ The consequence of this mass production and usage, the contamination of manganese compounds to the environment is increasing day-by day. Though Manganese is not a heavy metal, lethal dosage half population of this material appreciably high (acute oral $\mathrm{LD}_{50}$ of $>3478$ $\mathrm{mg} / \mathrm{kg}$ with reference to rat) 9 and non carcinogenic compound, it creates lot of several health issues at high concentration level in drinking water such as Alzheimer, Parkinson like disease and

\footnotetext{
a Department of Chemical Sciences, IISER-Mohali, SAS Nagar, Punjab, India. Fax:2240266,2240124; Tel:9840671987; E-mail:esakkikarthik85@gmail.com

$\dagger$ Electronic Supplementary Information (ESI) available: [Table of various Mn3O4 and $\mathrm{MnO}_{2}$ catalyst activity in OER, FE-SEM images and EDS elemental composition, TEM images, Raman spectra and TGA graphs]. See DOI: 10.1039/b000000x/
}

neurological disorders. 10 Recently, M. Aschner et al. reported that the health hazardous effect and seriousness of manganese contamination in drinking water, soil and air. In that, they have shown manganese neurotoxicity effect from C.elegans to human. $\frac{1112}{112}$ Further manganese elements react with other pollutant compound such as DDT, which affects river lives severely. S. Medrano et al. reported that the toxic effect of these co-pollutant nature of $\mathrm{Mn}$ is much more harmful than pesticides alone.13 S. F. Ali et al. reported that the generation of Reactive Oxygen species(ROS)from manganese based pollutant and their effects, also he confirmed that manganese in valency of three is more potential to generate ROS than $\mathrm{Mn}(\mathrm{II}) \cdot{ }^{[14} \mathrm{H}$. Ahsan et al reported that the reactive oxygen species can be a cause of cancer, which facilitate the DNA oxidative damages. 15 These reports exemplified the harmful nature of manganese based pollutants. The dry cell is fully made up of $\mathrm{MnO}_{2}$ compound, which is converted to several reduced form of lower oxides during discharging process, which scientific society has not been fully aware about the effect of this waste. Thus, the waste dry cell could solely be a main cause of manganese based pollution. Though this is an old technology, material based investigation is limited in modern literature. The environmental cause and high usage of this technology alarm us to revisit these materials with the help of modern science \& technology. Because of portability, cheap and easy fabrication of this energy conversion technology cannot be forbidden and our modern world needs more batteries to solve energy crisis. Recently researchers are showing interest in the area of investigating electrochemical application on waste 
batteries such as supercapacitor application and water splitting reaction from used lithium ion battery materials $\left(\mathrm{LiCoO}_{2}\right) \cdot \underline{1617}$ These reports emphasized that currently scientists are trying to find suitable methodology to utilize the waste material, specifically electrochemical applications for attaining pollution free environment. Further, dry cell is a type of non-rechargeable battery, it has inside hazardous multi-oxides of manganese materials, which either has to be disposed properly or reused in another applications to avoid aforementioned environmental problem. General chemical reaction of discharging process of this cell is shown in equation (1) 18

$$
\begin{aligned}
& \mathrm{Zn}+2 \mathrm{MnO}_{2}+2 \mathrm{NH}_{4} \mathrm{Cl} \stackrel{\text { Discharging }}{\longrightarrow} \mathrm{ZnCl}_{2}+\mathrm{Mn}_{2} \mathrm{O}_{3}+2 \mathrm{NH}_{3}+ \\
& \mathrm{H}_{2} \mathrm{O} \ldots . .(1) \\
& \mathrm{ZnCl}_{2}+2 \mathrm{NH}_{3} \rightarrow \mathrm{Zn}\left(\mathrm{NH}_{3}\right)_{2} \mathrm{Cl}_{2} \ldots . .(2) \\
& \quad \text { In addition to } 1 \text { and } 2 \text { reactions, there are other reactions }
\end{aligned}
$$
like $\mathrm{Mn}_{3} \mathrm{O}_{4}$ formation, reaction of $\mathrm{Zn}^{2+}$ with $\mathrm{MnO}_{2}$ and $\mathrm{Mn} 3 \mathrm{O} 4$ whereby the penetration of $\mathrm{Zn}^{2+}$ to $\mathrm{MnO}_{2}$ and $\mathrm{Mn}_{3} \mathrm{O}_{4}$ result in the formation of $\mathrm{Zn}$ doped Mn oxides. This zinc doping also depends on the rate of discharging, temperature and inside material quality such as membrane (ammonium chloride electrolyte soaked cotton served as an ionic conductive membrane) and distance between carbon rod ( + ) and Zn-plate(-).

In general, the manganese based oxides have excellent stability against chemical, 19 electrochemical ${ }^{20}$ and thermal condition and it cannot be easily converted to source element manganese. Pyrometallurgy and hydro-metallurgical methods are present industrial routes for waste battery recycling process,, 21 but it needs enormous energy. High thermal reaction, electrolysis or vigorous chemical treatment such as $\mathrm{H}_{2} \mathrm{SO}_{4}$ with oxalic acid as reducing agent may be useful to recycle and purify this waste materials. ${ }^{22}$ Unfortunately these multi-oxide solid manganese materials recycling technology needs more energy than manganese mining. Owing to this high cost problem, people are not showing interest on recycling technology. Hence, we need focus on reusing these waste materials to save our environment from battery waste. All manganese based oxides showed appreciable electrocatalytic activity towards water oxidation ${ }^{23}$ and reduction reaction. 24 Manganese has exhibited excellent potential to stabilize the oxo-compound, it is evident that many manganese based oxocompound is reported in literature.25/26/27 This oxo-phillic nature of manganese based oxides makes superior electrochemical water oxidation catalyst than reduction. ${ }^{28} \mathrm{Mn}$ based oxides can thermo chemically oxidize the water at low temperature, it is evident that this compound become a excellent electrocatalyst. ${ }^{29} \mathrm{D}$. G. Nocera et al., reported the OER activity of $\mathrm{MnO}_{2}$, he proposed $\mathrm{Mn}_{3} \mathrm{O}_{4}$ intermediate formation from $\mathrm{MnO}_{2}$ during OER, which later converted to disordered $\gamma-\mathrm{MnO}_{2}$. This report suggested that OER on manganese oxides involve several intermediate oxides such as from $\mathrm{MnO}_{2}, \mathrm{Mn}_{3} \mathrm{O}_{4}$ and $\mathrm{MnO}_{X} \cdot \frac{30}{30}$ These materials might be probably generated during dry cell discharging process, which is investigated in this report. S Fiechter et al., thoroughly studied the electrocatalytic efficiency in oxygen evolution reaction on various manganese based oxides namely $\mathrm{MnO}_{x}, \mathrm{Mn}_{2} \mathrm{O}_{3}$, and $\mathrm{Mn}_{3} \mathrm{O}_{4}$ and among them $\mathrm{Mn}_{2} \mathrm{O}_{3}$ showed better performance. ${ }^{31}$ In this study, we have analyzed the fresh and used dry cell materials with the help of XRD, SEM-EDS, TEM, Raman and contact angle studies. The electrocatalytic activity of these material was studied in OER, we have observed the discharged dry cell material exhibited OER bench marking current $10 \mathrm{~mA} . \mathrm{cm}^{-1}$ at $525 \mathrm{mV}$, which is $100 \mathrm{mV}$ lesser than fresh dry cell material activity as shown in Fig1 This electrocatalytic efficiency of used dry cell is comparable with previous literature reported manganese based electrocatalyts shown in Table (ESI-1).

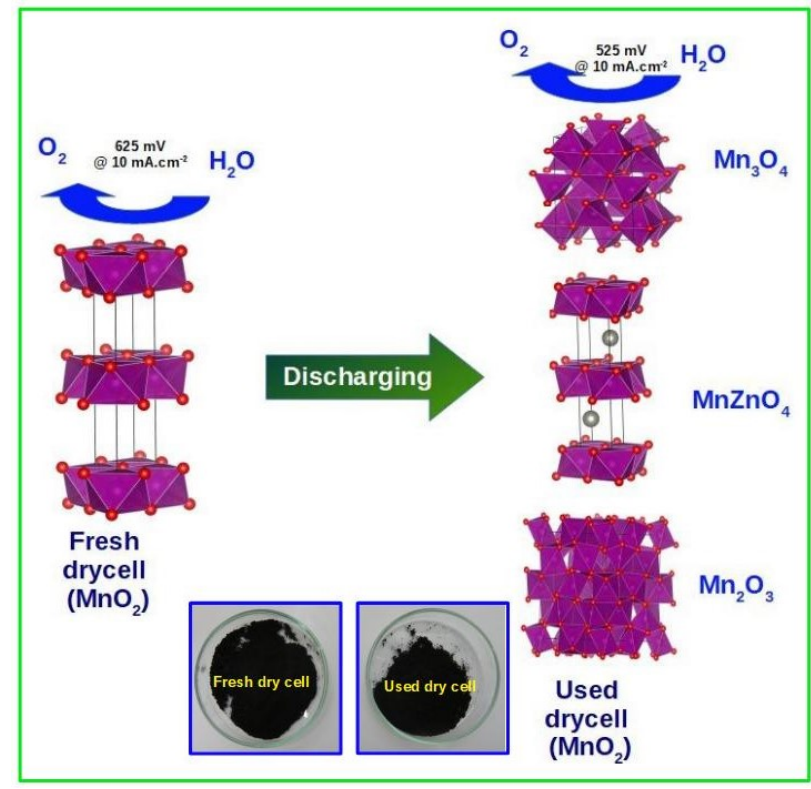

Fig. 1 Schematic of OER activity on fresh and used dry cells, insert picture: appearance of fresh and used drycell material.

\section{Experimental}

\subsection{Materials}

Analytical grade(A.R) chemicals such as acetone, propanol, sodium hydroxide and 5\% Nafion solution were purchased from Sigma Aldrich Inc. Fresh and used commercial dry cells were collected from local shop. All solutions were prepared using Milli-Q water $($ Resistance $=18.2 \mathrm{M} \Omega . \mathrm{cm})$.

\subsection{Components of dry cells}

Figure 2 shows the components of commercial dry cell. After removing commercial outside cover, inside polymer material insulated zinc plate covered cylindrical dry cell ${ }^{32}$ shown in figure2(A)I, observed polymer insulation prevent the dry cell from short circuit. The graphite rod (cathode), Zn plate (anode) and ionic conductive cotton paper between cathode and anode were presented in Figure 2

\subsection{Extraction of Manganese oxides from dry cell}

Commercial dry cell outside cover was carefully removed and followed by detaching insulating material, as shown in Fig 2AII. Inside zinc plate and carbon rod were manually separated from dry cell oxides. In the case of used dry cell, zinc would be penetrated to dry cell material during discharging process, zinc 

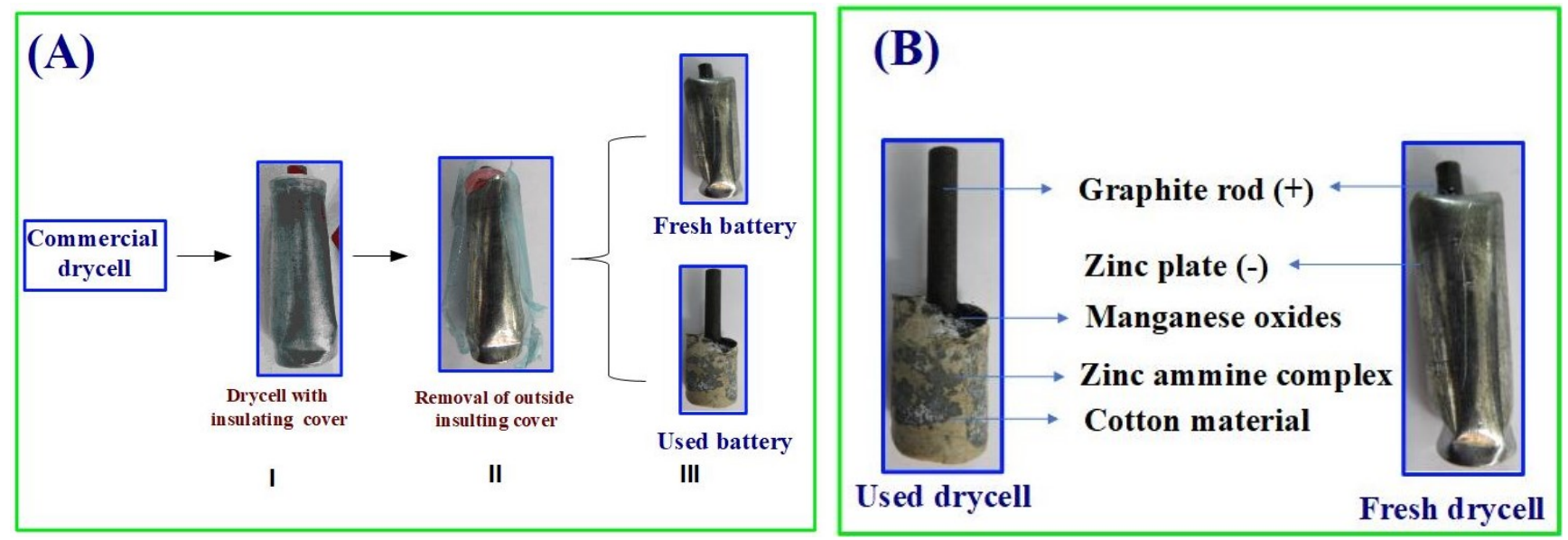

Fig. 2 A and B: Images of step-by-step opening and parts of used and fresh commercial dry cell respectively.

chloride and ammonia formed at the manganese oxide matrix, shown equation(2). As per equation (3), $\mathrm{ZnCl}_{2}$ and ammonia spontaneously react to form water soluble zinc-ammine complex $\left(\mathrm{Zn}\left(\mathrm{NH}_{3}\right)_{2} \mathrm{Cl}\right) .{ }^{18}$ Simultaneously, formed $\mathrm{ZnCl}_{2}$ etched cotton paper in used dry cell, shown in Figure2AIII. To remove these complex and binding material from collected samples, it was thoroughly washed initally with Milli-Q water and followed by acetone for three times. In this way washed oxides were dried at 70 ${ }^{\circ} \mathrm{C}$ for 12 hrs to remove solvents.

\subsection{Characterization}

Transmission Electron Microscopy (TEM)studies of samples were performed using JEOL-F200 machine with operating voltage of $200 \mathrm{kV}$, Field emission filament ZrO/W(100) used as an electron source and image captured using GATAN963 camera. SEM images were taken using JEOL(JSM-7600F model) machine, thereby solid samples were taken on conductive carbon tape. Thermal analysis such as TGA was done using SHIMADZU machine (Model No: DTG-60H), $3 \mathrm{mg}$ of sample was taken in alumina pan to conduct this characterization. FT-IR studies were carried out using Perkin Elmer (spectrum two) Instrument with the help of $\mathrm{KBr}$ pellet. XRD analysis was performed using Rigaku-Ultima IV machine and $\lambda=1.5418,40 \mathrm{eV}, 40 \mathrm{~mA}$ ) X-ray parameters has been used. Raman spectra were recorded using Renishaw (ut) instrument with the $\lambda=530 \mathrm{~nm}$ green laser as a light source.

\subsection{Electrochemical Characterization}

All electrochemical measurement was performed by three electrode system using CHI760E workstation at RT, wherein $1.5 \mathrm{~mm}$ dia Glassy Carbon(GC) was used as a working electrode. Platinum wire and $\mathrm{Hg} / \mathrm{HgO}(0.1 \mathrm{M} \mathrm{NaOH})$ served as a counter and reference electrode respectively. For comparison, all voltammogram potential scale was converted to R.H.E using conversion factor of $932 \mathrm{mV}$. The catalyst ink preparation for material drop-casting on GC surface adopted procedure followed; $3 \mathrm{mg}$ of dry cell material was taken in $100 \mu \mathrm{l}$ of Milli-Q water and $5 \mu \mathrm{l}$ of $5 \%$ naffion binder added to this mixture, which was sonicated for 30 minutes to attain proper homogeneous solution. $3 \mu$ l of these aliquot was drop-casted on GC surface. The drop-casted electrode was kept at RT for 12 hours to make stable catalyst-nafion film. Since nafion is a proton exchange membrane, the ionic conductivity is accompanied by $\mathrm{H}^{+}$ion transport, here low concentration of nafion was used as a binder material in alkaline medium, high concentration of nafion binder enhances uncompensated resistance $\left(\mathrm{IR}_{u}\right)$ across the interface.

\subsection{Drycell discharging}

Fully discharging of dry cell was confirmed using MASTECH(Model: MS8264) multimeter Figure shown in (ESI-S1). Using this technique, the output current was monitored. Fully discharged dry cell did not show any current output instead charged one exhibited $80 \mathrm{~mA}$. The controlled discharging was done by short circuiting cells, thereby dry cell was spontaneously discharged and to generate heat. The heat generation is due to internal resistance from manganese materials. Using this method we have discharged dry cell for different time period for XRD analysis.

\section{Results and discussion}

Before analyzing these mixed Mn-oxide materials electro catalytic water oxidation efficiency from fresh and used dry cells, we have analyzed chemical nature of both the materials with the help of XRD TEM, SEM-EDS Raman and TGA analysis as shown in Fig 3 and (ESI-S2-7). These analyses revealed the reason behind high electrocatalytical activity of used dry cell materials.

\subsection{Electron microscopic analysis and X-ray diffraction anal- ysis}

The TEM images of both materials showed similar graphene like morphology and particle features, it indicated that the discharging process doesn't affect the material morphology and showed the average particle size is less than $100 \mathrm{~nm}$. Same particle size $(c a .10 \mu \mathrm{m})$ of these has proven that the discharging process couldn't affect the particle size also. We are unable to identify the difference between these materials using this technique. The transparent film was seen, which could be appeared from the car- 
bon compound present in those materials. Due to the inability of finding out the difference between these materials using above studies, XRD analysis was performed. The XRD pattern of fresh dry cell material was matched with $\mathrm{MnO}_{2}$ (Akhtenskite mineral) and corresponding ICSD reference pattern. No: $98-005-1756$ of $\mathrm{MnO}_{2}$ (P63/mmc). After discharging the dry cell, XRD pattern has severely been changed as shown in Fig 3 C and ESI-S3.
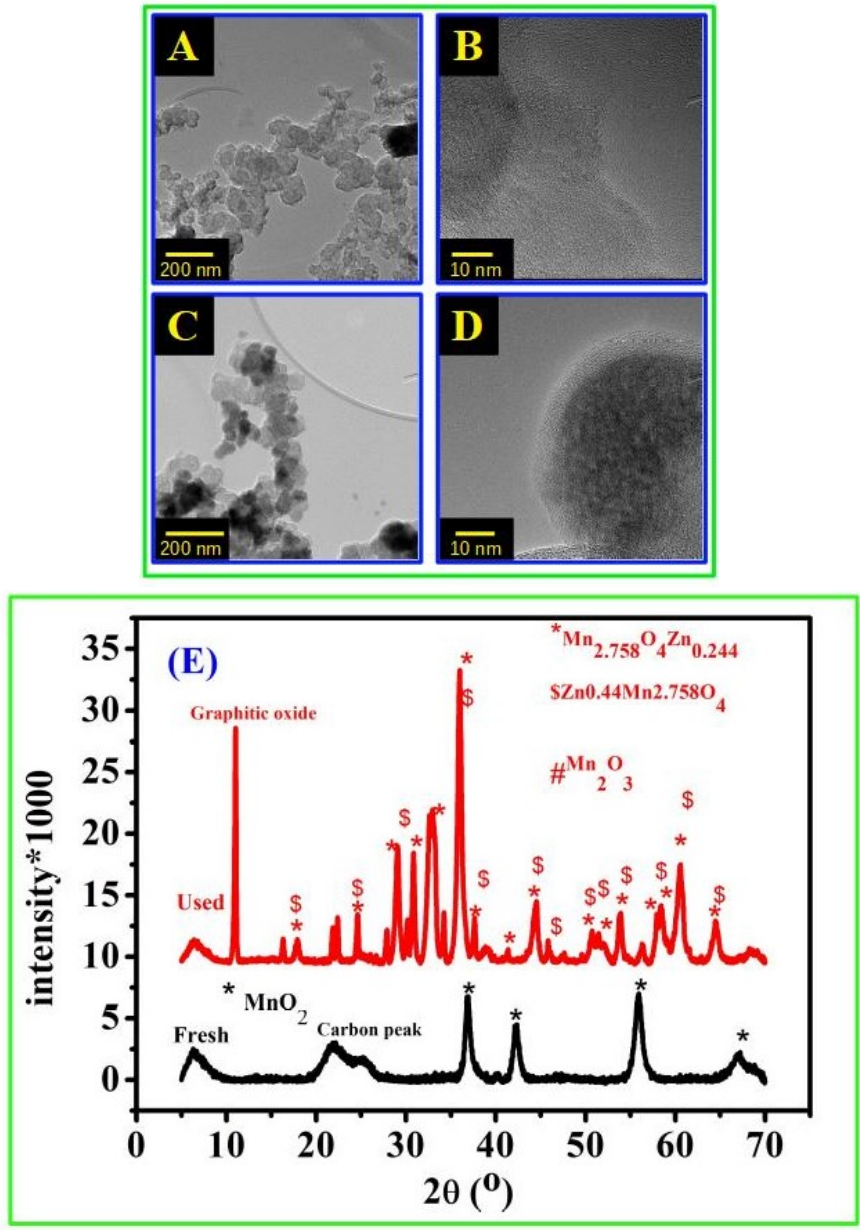

Fig. 3 A,B and C,D: TEM images of fresh and used dry cell materials respectively, E: Powder XRD patterns of fresh (red) and used (black) dry cell materials.

These changes are due to the formation of $\mathrm{Mn}_{2.758} \mathrm{O}_{4} \mathrm{Zn}_{0.244}$, and $\mathrm{Mn}_{3} \mathrm{O}_{4}$. This pattern well matched with ICSD reference codes $98-006-7432$ of $\mathrm{Mn}_{2.758} \mathrm{O}_{4} \mathrm{Zn}_{0.244}$ (space group: I41/amd) and $98-008-9972$ of $\mathrm{Mn}_{3} \mathrm{O}_{4}$ (space group:I41/amd). $\mathrm{MnO}_{2}$ to $\mathrm{Mn}_{2.758} \mathrm{O}_{4} \mathrm{Zn}_{0.244}$ or $\mathrm{Mn}_{3} \mathrm{O}_{4}$ conversion would be facilitated by inside generated electrochemical potential. In addition with $\mathrm{Mn}_{2.758} \mathrm{O}_{4} \mathrm{Zn}_{0.244}$ material, small amount of $\mathrm{Mn}_{2} \mathrm{O}_{3}$, un-reacted compound $\mathrm{MnO}_{2}[3]$ and graphene oxide (GO) peak were found at $2 \theta$ value of 11.09 .34 Either filler carbon oxidation or exfoliation of layers from graphite anode electrode could be a reason for forming graphene oxide at discharging time. $\frac{35}{35}$ From the (FWHM) of this peak, inter layer distance of graphene oxide was $7.99 \mathrm{~nm}$ calculated using equation below. $\frac{36}{6}$

$$
\mathrm{d}=(\lambda / 2(\sin \theta))=(0.154 \mathrm{~nm}) / 2(\sin 5.508)) . .
$$

Where $(\lambda)$ X-ray wavelength is $0.154 \mathrm{~nm},(\theta)$ peak position from XRD pattern is 11.016. Fresh dry cell material XRD pattern showed higher FWHM(ca.0.52 at $2 \theta$ 36.8) than used material (ca. 0.38 at $2 \theta$ 35.9), it conveyed that the discharging process has changed the amorphous nature of fresh dry cell solid material $\left(\mathrm{MnO}_{2}\right)$. The reduction of $\mathrm{MnO}_{2}$ and proper crystallization may occur during discharging process, which leads to form high crystalline nature of $\mathrm{Mn}_{2.758} \mathrm{O}_{4} \mathrm{Zn}_{0.244}$ and $\mathrm{Mn}_{3} \mathrm{O}_{4}$. These changes in used dry cell chemical composition was further analyzed using controlled XRD analysis with different discharging time such as $5 \mathrm{hr}, 10 \mathrm{hr}$ and fully discharged conditions. The GO

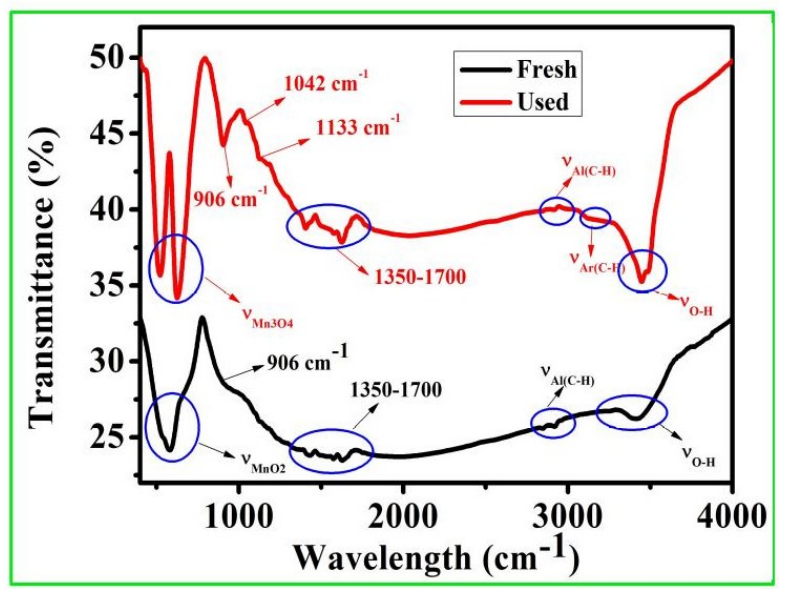

Fig. 4 FT-IR spectra of Fresh(black) and used(red) dry cell materials.

appearance and increasing crystalline nature of XRD pattern was reproduced in every discharging process. There is no systematic changes observed in all chrono-discharging XRD analysis. It emphasized that the spontaneous changes happened in discharging process. However, the used cell contained graphene oxide, fresh cell also have good-enough amount of conductive carbon materials (for reducing internal resistance), mostly these materials are in the form of graphitic in nature. The SEM-EDS analysis revealed that the surface morphology and elemental composition shown in figure(ESI-4 and 5a-c). It explained ca. $28 \%$ increases carbon content in used dry cell from fresh dry cell $32 \%$ and ca, $7 \%$ zinc appearance on used dry cell material. These observations give a clue that, in a dry cell, the increased carbon content as seen from the carbon exfoliation is because of the anodic grahite rod during discharging and the doping of $\mathrm{Zn}$ is mainly attributed to the discharging mechanism of cathodic zinc plate.

\subsection{Raman and thermal analysis}

These carbon materials nature were studied using Raman spectral analysis as Figure shown in (ESI-S6). The clear D and G band was observed for both the cell materials. $\mathrm{I}_{D} / \mathrm{I}_{G}$ (Ratio of intensity of two peaks in Raman spectrum) of fresh and used dry cell materials 1.025 and 1.1752 respectively 37 . It clearly showed that the higher carbon defective phase present in used dry cell than that of the fresh one. It supports the XRD results of graphene oxide formation. Besides, the material was characterized using thermal 
studies such as thermogravimetric (TGA) analysis, Figure shown in (ESI-S6). The temperature vs. weight loss TGA curve of fresh material has different thermal decomposition characteristics from used dry cell, shown in figure (ESI-S7).
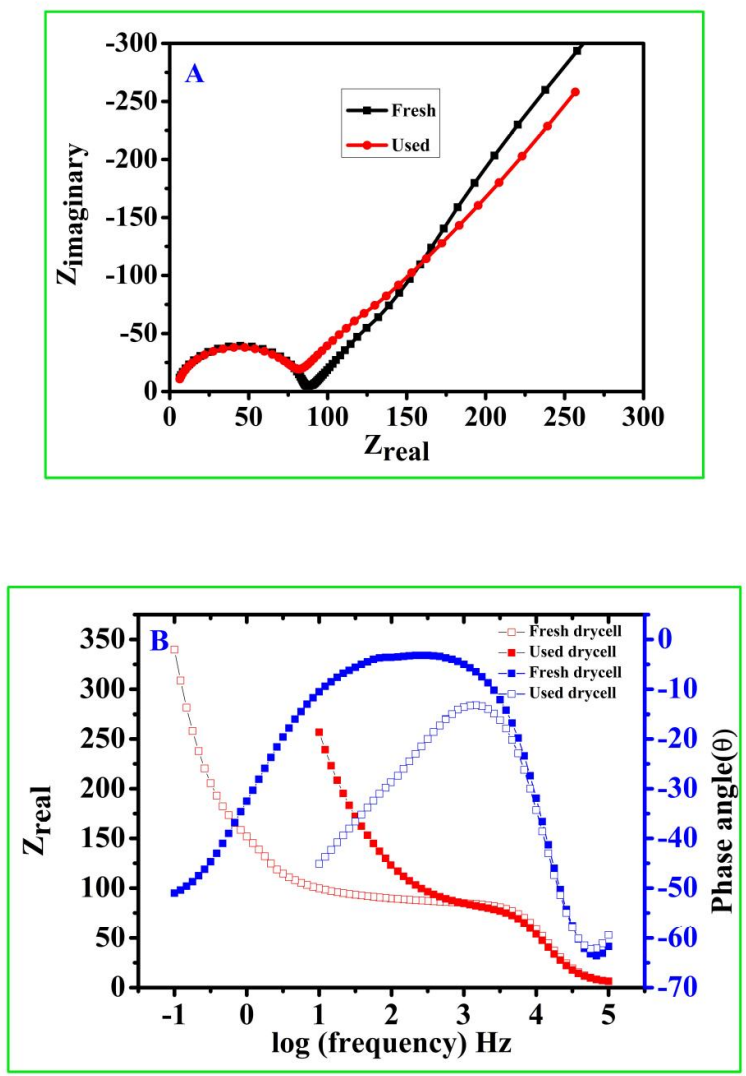

Fig. $5 \mathrm{~A}$ and $\mathrm{B}$ : Nyquist and bode impedance plot of dry cell material at equilibrium condition.

Material from fresh dry cell in $\mathrm{N}_{2}$ atmosphere did not show any weight loss upto $400{ }^{\circ} \mathrm{C}$ but in an air atmosphere showed series of weight losses starting from 27.5 to $610^{\circ} \mathrm{C}$. The initial $1.3 \%$ weight loss upto $100{ }^{\circ} \mathrm{C}$ could be attributed to evaporation of easily volatile compound from sample. The next $2 \%$ weight loss started from 100 to $240{ }^{\circ} \mathrm{C}$ may be from loss of moisture. Followed by $3.5 \%$ weight loss appeared in the range of 240 to $400{ }^{\circ} \mathrm{C}, 38$ which would be from loss of carbon. In the range of $440-610{ }^{\circ} \mathrm{C}$ almost 20 and $24 \%$ weight loss were observed in air and $\mathrm{N}_{2}$ atmosphere respectively, which could be ascribed to the loss of oxygen from $\mathrm{MnO}_{2}$. $3.5 \%$ increased weight loss in $\mathrm{N}_{2}$ medium is due to oxygen removal accompanied with carbon oxidation by oxygen from $\mathrm{MnO}_{2}$ decomposition reaction. The $\mathrm{O}_{2}$ removal from $\mathrm{MnO}_{2}$ at $483{ }^{\circ} \mathrm{C}$ to form $\mathrm{Mn}_{2} \mathrm{O}_{3}$, shown in equation(4) 39

$$
\mathrm{MnO}_{2} \underset{483^{\circ} \mathrm{C}}{\longrightarrow} 2 \mathrm{Mn}_{2} \mathrm{O}_{3}+\mathrm{O}_{2} \ldots . .(4)
$$

Conversely, used dry cell material showed similar weight loss pattern in $\mathrm{N}_{2}$ and air atmosphere. Apart from initial $2.3 \% \mathrm{H}_{2} \mathrm{O}$ loss, next 6.3 and $4 \%$ carbon loss was seen in air and $\mathrm{N}_{2}$ atmosphere from graphene oxide(GO) in the range $169-421{ }^{\circ} \mathrm{C}$. This higher weight loss was seen in air atmosphere may be understood that the complete oxidation of carbon under air. Next 8 and 9.6 $\%$ weight losses were seen in air and $\mathrm{N}_{2}$ atmosphere in the range of $420-640{ }^{\circ} \mathrm{C}$, it is from unreacted $\mathrm{MnO}_{2}$ decomposition at discharging process. Because of unoxidized carbon might oxidized in $\mathrm{N}_{2}$ atmoshphere at higher thermal region of $420-640^{\circ} \mathrm{C}$, thus reflect $1.6 \%$ higher weight loss than air. In used dry cell, carbon decomposition was observed even at $\mathrm{N}_{2}$ atmosphere also, this could be understood that the presence of graphene oxide(GO), which can supply oxygen for carbon decomposition. $\mathrm{MnO}_{2}$ thermal decomposition has been shown in equation (4). For comparison, fresh and used dry cell material properties are tabulated in table 1.

\subsection{Mechanism of formation of graphitic oxide in dry cell}

The graphene oxide formation in Lechlanche cell could be explained through oxygen reduction reaction (ORR), this process accompanied with $\mathrm{MnO}_{2}$ reduction at graphite- $\mathrm{MnO}_{2}$ interface. Anode manganese dioxide reduction with cathode $\mathrm{Zn}$ oxidation is overall electrochemical reaction in this cell, shown in equation (5)

$$
\begin{aligned}
& 2 \mathrm{MnO}_{2}+2 \mathrm{NH}^{4+}+2 \mathrm{e}^{-} \stackrel{\text { D ischarging }}{\longrightarrow} \mathrm{Mn}_{2} \mathrm{O}_{3}+2 \mathrm{NH}_{3}+\mathrm{H}_{2} \mathrm{O} \ldots . . .(5) \\
& \mathrm{O}_{2}+\mathrm{e}^{-} \longrightarrow\left[\mathrm{O}_{2}{ }^{--}+4 \mathrm{H}^{+}\right]_{\text {intermediate }} \longrightarrow 2 \mathrm{H}_{2} \mathrm{O} \ldots . .(6)
\end{aligned}
$$

In the above equation, product water and $\mathrm{Mn}_{2} \mathrm{O}_{3}$ are forming from reactant $\mathrm{MnO}_{2}$, in which the electrochemical potential difference between $\mathrm{Zn}_{\text {oxidation }}$ and $\mathrm{MnO}_{2 \text { reduction }}$ is not only reducing $\mathrm{Mn}_{2} \mathrm{O}_{3}$ but also oxygen too. The result of oxygen reduction gives water through super oxide intermediates, shown in equation (1). The oxygen reduction coupled with zinc oxidation is well known the area of $\mathrm{Zn}$-air batteries ${ }^{40}$, overall potential $\left(\mathrm{O}_{2 \text { reduction }}{ }^{-}\right.$ $\left.\mathrm{Zn}_{\text {oxidation }}\right)=1.23-0.76 \mathrm{~V}=0.47 \mathrm{~V}$. This over all positive potential facilitate ORR at the graphitic anode electrode with $\mathrm{MnO}_{2}$ matrix. These extremely reactive super oxides convert graphite anode to graphitic-oxide materials by etching carbon surfaces.

\subsection{FT-IR analysis}

Fourier transform Infrared (FT-IR) spectra of both samples are presented in figure 4 which showed clear difference in the region of $400-700 \mathrm{~cm}^{-1}$. Closer view of figure insists that, fresh cell sample exhibited single peak corresponded to $\mathrm{MnO}_{2}$ and double peaks were seen in used sample, which corresponded to $\mathrm{Mn}_{3} \mathrm{O}_{4}$. The same behavior of FT-IR of $\mathrm{MnO}_{2}$ and $\mathrm{Mn}_{3} \mathrm{O}_{4}$ was earlier discussed by F.Cui et al. ${ }^{[3]}$ Hydroxyl group stretching peak intensity in used sample predominately higher than fresh one. It confirmed that the graphitic oxides has more no. of hydroxy group than initial carbon materials. Discharging process generated high amount of defective sites on carnbon surface by generating hydroxyl group. IR peaks in the range of $1350-1700 \mathrm{~cm}^{-1}$ can be interpreted that mixed peaks of $\mathrm{OH}, \mathrm{C}-\mathrm{H}$ bending and $\mathrm{C}=\mathrm{O}$ stretching. The peaks in at 1042 and $1133 \mathrm{~cm}^{-1}$ was construed to $\mathrm{C}-\mathrm{O}$ bond from graphene oxide, which was not seen in fresh battery material. We have observed aliphatic $\mathrm{C}-\mathrm{H}$ stretching on fresh sample but used sample sample has shown both aliphatic 
and aromatic C-H stretching.

Table 1 Comparison of fresh and used dry cell material properties

\begin{tabular}{lll}
\hline Property & Fresh dry cell material & Used dry cell material \\
\hline Appearance & Black powder & Black powder \\
Chemical nature & $\mathrm{MnO}_{2}$ & $\mathrm{Mn}_{2.758} \mathrm{O}_{4} \mathrm{Zn}_{0.244}$ \\
Carbon nature & Conductive carbon & $\begin{array}{l}\text { Conductive carbon with } \\
\text { graphene oxide }\end{array}$ \\
Wettablity & Hydrophobic & Hydrophilic \\
$\begin{array}{l}\text { Electrocatalysis in } \\
\text { OER }\left(\eta, j_{0}\right)\end{array}$ & $3.11^{*} 10^{-8}, 626 \mathrm{mV}$ & $5.68 * 10^{-6}, 526 \mathrm{mV}$ \\
Nature of Manganese & $\mathrm{MnO}_{2}$ & $\mathrm{Mn}_{3} \mathrm{O}_{4}, \mathrm{MnZnO}_{4}$ \\
\hline
\end{tabular}

\subsection{Electrocatalytic studies}

Electro-catalytical efficiency of oxygen evolution reaction(OER) of fresh and used dry cell material is shown in Fig 6 It corroborated the higher electrocatlytic activity of used dry cell, nearly $100 \mathrm{mV}$ decreased overpotential observed at OER current density of $10 \mathrm{~mA} . \mathrm{cm}^{-2}$ than fresh one. The fresh dry cell material showed higher background current than used one, which conveyed $c a$. 5 times higher double layer capacitance $\left(\mathrm{C}_{d l}\right)$ nature. Further we have observed the OER onset potential of used dry cell material is $120 \mathrm{mV}$ lower than fresh one. For comparison with earlier report, IR corrected oxygen evolution has been presented in Fig. 6B, it indicated absolute OER activity and showed $\eta=526 \mathrm{mV} @ 10 \mathrm{~mA} . \mathrm{cm}^{-2}$. IR correction of $6 \Omega$ from solution resistance $\left(\mathrm{R}_{s}\right)$ was done using impedance analysis as shown in fig5. Comparison with $\mathrm{Mn}_{2} \mathrm{O}_{3}, \mathrm{MnO}_{2}$ exhibited poor electrocatalytic activity towards OER, which was recently observed by Fiechter et al. $\frac{31}{31}$ When dry cell discharges, the inside $\mathrm{MnO}_{2}$ reduced to form highly electroactive $\mathrm{Mn}_{2} \mathrm{O}_{3}$ and various amount of zinc doped with $\mathrm{Mn}_{2} \mathrm{O}_{3}$ present with some un-reacted $\mathrm{Zn}$-doped $\mathrm{MnO}_{2}$. Hence, this used material exhibited better OER electrocatalytic activity than fresh dry cell $\mathrm{MnO}_{2}$. The plot between $\operatorname{overpotential}(\eta)$ vs. $\log j$ Tafel analysis is shown in Fig.7, it presented the high electrocatalytic activity of used dry cell material Tafel slope of $105 \mathrm{mV} /$ decade, which is lower than fresh dry cell materials slope of $140 \mathrm{mV}$. Lower Tafel slope of used dry cell material corroborated the facile electron transfer in OER ${ }^{41}[42$ Equilibrium exchange current density $\left(j_{0}\right)$ of fresh and used dry cell material was calculated by extrapolating Tafel plot, which was $3.11 * 10^{-8} \mathrm{~mA} . \mathrm{cm}^{-2}$ and $5.68 * 10^{-6} \mathrm{~mA} . \mathrm{cm}^{-2}$ respectively. The used dry cell $\left(j_{0}\right)$ was two decades higher than fresh dry cell materials, it supported fast kinetics of electron transfer on used dry cell material than fresh one. ${ }^{43}$ The onset of OER was also $100 \mathrm{mV}$ negatively shifted. The high capacitance of fresh dry cell may be correlated by high surface area such that electrochemical active $\mathrm{MnO}_{2}$ would be masked by carbon matrix. In the case of used dry cell, the active manganese oxide protrude outside and exposed to the electrolytes, thus gave lower capcitance since both have same particle size. Manganese oxide protruding could be facilitated by
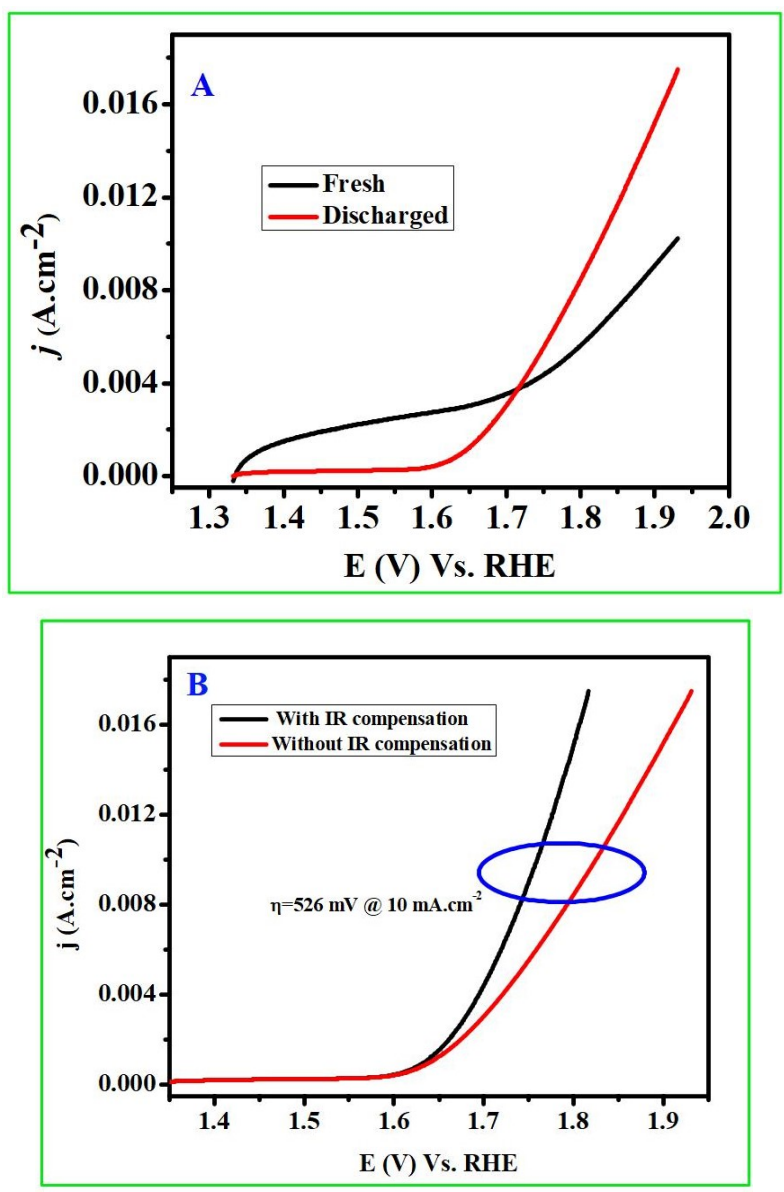

Fig. 6 A: Linear Scan Voltammetry (LSV) of fresh and used dry cell material water oxidation curve and B: LSV of water oxidation reaction on used dry cell material with and without IR compensation at a scan rate of $5 \mathrm{mV} / \mathrm{s}$ in $0.1 \mathrm{M} \mathrm{NaOH}$.

discharging process The accelerated stability test of used dry cell material using 5000 potential cycling in OER range of 0.2 to 1.8 $\mathrm{V}$ vs. R.H.E. Fig. $7 \mathrm{~B}$ has shown only $0.2 \%$ current reduction at $1.852 \mathrm{~V}$ after 5000 accelerated potential cycling. Small amount of decrease in material leaches was seen in decreasing double layer capacitance in figure $7 \mathrm{~B}$ shown by inserting circle. Equilibrium state impedance analysis of these materials was presented in Figure5. Nyquist plot impedance analysis revealed charge transfer resistances $\left(\mathrm{R}_{c t}\right) \mathrm{s}^{\prime}$ of fresh and used dry cell materials are 84 and $87 \Omega$ respectively. Due to capacitance difference of used and fresh dry cell, these impedance-spectra were performed in different applied frequencies to achieve Warburg impedance, which was clearly seen in Bode plot. Bode plot explicit that operating frequency range 10 to $10^{5} \mathrm{~Hz}$ and 0.1 to $10^{5} \mathrm{~Hz}$. High capacitance nature of fresh dry cell material and resistance increase the time constant $(\mathrm{RC}=\tau)$, thus shifted Warburg impedance to lower frequency region .

Contact angle experiment revealed that the amount of water interaction with catalyst, as shown in Fig. 75 and D. It displayed used dry cell material has $19^{\circ}$ contact angle $\left(\theta=100^{\circ}\right)$ lesser than fresh dry cell material $\left(\theta=119^{\circ}\right)$, the lower contact angle could be understood by formation of high surface polarity $\mathrm{Mn}_{3} \mathrm{O}_{4}$ 

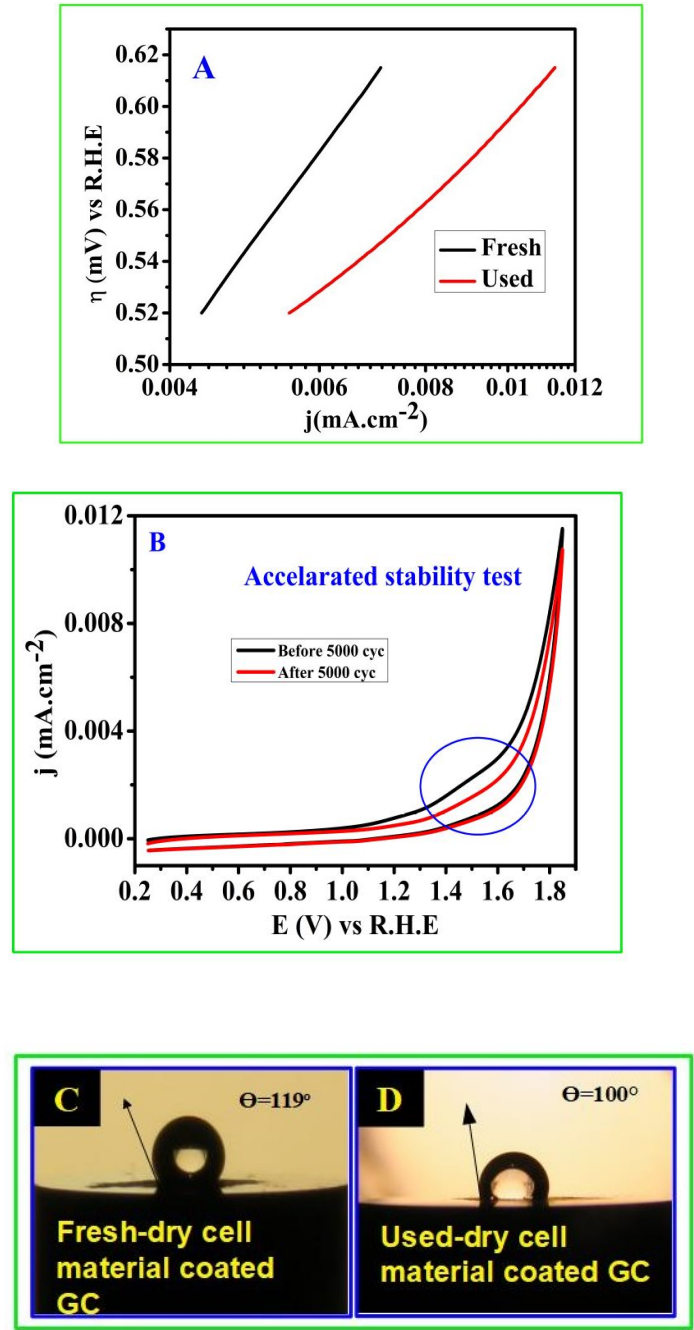

Fig. $7 \mathrm{~A}$ and B: Tafel plots and accelerated potential cycles of OER on fresh and used dry cells; $C$ and D: Contact angle images of fresh and used dry cell material coated GC electrodes.

formation and the in-situ formation of graphene oxide. Contact angle experiment has proven the higher hydro-philicity of used dry cell material than fresh one, which supported the excellent interaction and high affinity with water of used dry cell material. These high hydrophilic of used dry cell has proven the higher electrocatalytic activity in OER 44 . This material contact angle lies in semi-hydrophilic region, which is suitable for both OER and ORR.

\section{Conclusions}

In summary, we have observed high electrocatalytic activity on used dry cell than fresh in oxygen evolution reaction and seen $100 \mathrm{mV}$ lesser OER overpotential for used dry cell materials than fresh dry cells to achieve OER bench marking current density of $10 \mathrm{~mA} \cdot \mathrm{cm}^{-2}$. The formation of intermediate $\mathrm{Mn}_{3} \mathrm{O}_{4}$ from fresh dry cell $\mathrm{MnO}_{2}$, developing hydro-philicity nature and generation of graphene oxide (GO) during discharging process enhance the electrocatalytic activity. Hence, in this report, we claimed that the dry cell discharging process is not only producing electrical energy but also activate $\mathrm{MnO}_{2}$ towards OER electrocatalysis. These findings are highly useful to reuse the used dry cell materials in the area of electrochemical energy conversion reactions as an electrocatyst, which enormously reduces dry cell contamination to environment from used dry cells.

\section{Conflicts of interest}

There are no conflicts to declare

\section{Acknowledgements}

This work was financially supported by National Postdoctoral Fellowhip (NPDF), DST-SERB, India (File No: PDF/2016/002519) and author P. Esakki Karthik acknowledged IISER-Mohali, Punjab for providing characterization facilities.

\section{Notes and references}

1 K. Takahashi, Electrochimica Acta, 1981, 26, 1467-1476.

2 N. C. Cahoon, Journal of The Electrochemical Society, 1952, 99, 343-348.

3 M. Cabral, F. Pedrosa, F. Margarido and C. Nogueira, Environmental technology, 2013, 34, 1283-1295.

4 J. Mehlig, Industrial \& Engineering Chemistry Analytical Edition, 1935, 7, 27-29.

5 R. Oka and T. Masui, RSC Adv., 2016, 6, 90952-90957.

6 D. G. Ellingsen, S. M. Hetland and Y. Thomassen, Journal of Environmental Monitoring, 2003, 5, 84-90.

7 T. Weldeslassie, H. Naz, B. Singh and M. Oves, Modern Age Environmental Problems and their Remediation, Springer, 2018, pp. 1-22.

8 W. Chen, X. Feng, J. Chen and L. Yan, RSC Advances, 2014, 4, $42418-42423$.

9 http://www.sciencelab.com/msds.php?msdsId $=9924585$.

10 A. P. Neal and T. R. Guilarte, Toxicol. Res., 2013, 2, 99-114.

11 A. N. Jensen and L. T. Jensen, Manganese in health and disease, The Royal Society of Chemistry, 2015, pp. P001-632.

12 T. V. P. A. B. B. Pan Chen, Sudipta Chakraborty and M. Aschner, Toxicology research, 2015, 4, 191-202.

13 M. JesÃžs, S. Sergio, E. SantosâĂŘMedrano Gustavo, G. Roberto, R. Israel, R. Roberto and D. Fernando, Environmental Toxicology and Chemistry, 2005, 24, 2037-2044.

14 S. F. Ali, H. M. Duhart, G. D. Newport, G. W. Lipe and W. Slikker, Neurodegeneration, 1995, 4, 329 - 334.

15 H. A. Gulam Waris, Journal of carcinogenics, 2006, 5, 1-8.

16 G. Gardner, D. N. Al-Sharab, Jafar, A. K. Go, Yong Bok, M. Greenblatt and G. C. Dismukes, Energy \& Environmental Science, 2016, 9, 184-192.

17 J. Wang, L. Li, H. Tian, Y. Zhang, X. Che and G. Li, ACS Applied Materials \& Interfaces, 2017, 9, 7100-7107.

18 A. Kozawa and R. A. Powers, Journal of Chemical Education, 1972, 49, 587-591.

19 E. de la Llave, E. Talaie, E. Levi, P. K. Nayak, M. Dixit, P. T. Rao, P. Hartmann, F. Chesneau, D. T. Major, M. Greenstein et al., Chemistry of Materials, 2016, 28, 9064-9076.

20 M. Feng, Q. Du, L. Su, G. Zhang, G. Wang, Z. Ma, W. Gao, X. Qin and G. Shao, Scientific reports, 2017, 7, 2219.

21 M. V. Gallegos, L. R. Falco, M. A. Peluso, J. E. Sambeth and 
H. J. Thomas, Waste Management, 2013, 33, 1483 - 1490.

22 R. N. Sahoo, P. K. Naik and S. C. Das, Hydrometallurgy, 2001, 62, 157-163.

23 M. M. Najafpour, G. Renger, M. HoÅĆẙ̊Ďska, A. N. Moghaddam, E.-M. Aro, R. Carpentier, H. Nishihara, J. J. Eaton-Rye, J.-R. Shen and S. I. Allakhverdiev, Chemical Reviews, 2016, 116, 2886-2936.

24 B. Maryam and S. Keith, ChemCatChem, 2017, 9, 4049-4052.

25 S. Hong, Y.-M. Lee, M. Sankaralingam, A. K. Vardhaman, Y. J. Park, K.-B. Cho, T. Ogura, R. Sarangi, S. Fukuzumi and W. Nam, Journal of the American Chemical Society, 2016, 138, 8523-8532.

26 A. Gunay and K. H. Theopold, Chemical reviews, 2010, 110, 1060-1081.

27 B. S. Mandimutsira, B. Ramdhanie, R. C. Todd, H. Wang, A. A. Zareba, R. S. Czernuszewicz and D. P. Goldberg, Journal of the American Chemical Society, 2002, 124, 15170-15171.

28 N. Danilovic, R. Subbaraman, K.-C. Chang, S. H. Chang, Y. J. Kang, J. Snyder, A. P. Paulikas, D. Strmcnik, Y.-T. Kim, D. Myers et al., The journal of physical chemistry letters, 2014, 5, 2474-2478.

29 B. Xu, Y. Bhawe and M. E. Davis, Proceedings of the National Academy of Sciences, 2012, 109, 9260-9264.

30 M. Huynh, C. Shi, S. J. L. Billinge and D. G. Nocera, Journal of the American Chemical Society, 2015, 137, 14887-14904.

31 A. Ramírez, P. Hillebrand, D. Stellmach, M. M. May, P. Bogdanoff and S. Fiechter, The Journal of Physical Chemistry C, 2014, 118, 14073-14081.
32 U. Mejia, Mario Y. AlvarezOscar, 1981 (1981-02-03) Us4248945a.

33 J. Zhao, J. Nan, Z. Zhao, N. Li, J. Liu and F. Cui, Applied Catalysis B: Environmental, 2017, 202, 509-517.

34 A. Jabbar, G. Yasin, W. Q. Khan, M. Y. Anwar, R. M. Korai, M. N. Nizam and G. Muhyodin, RSC Advances, 2017, 7, 31100-31109.

35 H. Wang, C. Wei, K. Zhu, Y. Zhang, C. Gong, J. Guo, J. Zhang, L. Yu and J. Zhang, ACS applied materials \& interfaces, 2017, 9, 34456-34466.

36 Y. Sheng, X. Tang, E. Peng and J. Xue, Journal of Materials Chemistry B, 2013, 1, 512-521.

37 A. C. Ferrari and J. Robertson, Physical review B, 2000, 61, 14095-14107.

38 Y.-F. Lee, K.-H. Chang, C.-C. Hu and K.-M. Lin, Journal of Materials Chemistry, 2010, 20, 5682-5688.

39 K. Terayama and M. Ikeda, Transactions of the Japan institute of metals, 1983, 24, 754-758.

40 J.-S. Lee, S. Tai Kim, R. Cao, N.-S. Choi, M. Liu, K. T. Lee and J. Cho, Advanced Energy Materials, 2011, 1, 34-50.

41 P. E. Karthik, C. Jeyabharathi and K. L. Phani, Chemical Communications, 2014, 50, 2787-2790.

42 N.-T. Suen, S.-F. Hung, Q. Quan, N. Zhang, Y.-J. Xu and H. M. Chen, Chemical Society Reviews, 2017, 46, 337-365.

43 S. Anantharaj, S. R. Ede, K. Karthick, S. S. Sankar, K. Sangeetha, P. E. Karthik and S. Kundu, Energy \& Environmental Science, 2018, 11, 744-771.

44 Y. Chen, Q. Zhou, G. Zhao, Z. Yu, X. Wang, S. X. Dou and W. Sun, Advanced Functional Materials, 2018, 28, 1705583. 